\title{
動態安定度に基づいた電力取引経路の優先順位付け手法 に関する基礎検討
}

\author{
正 員 斎藤 浩海 (東北大) \\ 正 員 皆藤 佳孝 (東京禹力) \\ 正 員 豊田 淳一 (八戸エ大)
}

\begin{abstract}
A Study on Screening of Electricity Transaction Path Based on Dynamic Stability Hiroumi Saitoh, Member (Tohoku University), Yoshitaka Kaito, Member (Tokyo Electric Power Company), Junich Toyoda, Member (Hachinohe Institute of Technology)
\end{abstract}

In a network open access environment, various electricity transactions with different contract paths will occur, and which tend to result in parallel flows. In order to reduce such kinds of power flows, series types of FACTS devices such as TCSC can be used. On the other hand, since the FACTS devices are effective means for stability enhancement, those devices will be utilized for the both purposes of power flow control and stabilizing control in the network open access environment.

This paper proposes a new concept of Transaction Path Filter (TPF) which can screen and order the electricity transactions from the viewpoint of parallel flow reduction and stabilizing ability of TCSC. In the TPF, first, the amount of compensation of TCSC is computed which is necessary for completely reducing the parallel flow of each transaction. Next, by using sensitivity analysis of eigenvalue, the effect of the compensation on stabilizing ability of TCSC is evaluated as the change in the real parts of eigenvalues corresponding to the focused oscillatory modes. Each transaction is classified into four ranks based on the necessary amount of compensation and the stabilizing ability, and then it is determined whether the transaction is accepted or not by system operators.

キーワード : 電力取引、パラレルフロー、動態安定度、順位付け、TCSC、FACTS

\section{1.まえがき}

近年の欧米で進められている送電ネットワーク利用の開 放化は、潮流制御を複雑化し、ネットワークセキュリティ の維持を困難にする頃向にある。たとえば、アメリカの卸 電力託送で採用されている契約パスベースの送電サービス 予約では、契約パス以外の系統へ流れ込む電力 (パラレル フローと呼ばれている）による線路過負荷などが問題とな っており、実潮流ベースの送電サービス予約および電力取 引削隇ルールなどのソフトウェア的な解決策が検討されて いる(1,2)。

一方、TCSC ゃ UPFC などの直列型 FACTS 機器は高 速な潮流制御を可能にし(5)、また電力動摇抑制などの安定 化制御にも有効である(3,4)。したがって、これらの FACTS 機器が導入された電力ネットワークでは、パラレルフロー などの潮流問題の解決と、系統安定度の維持とを、ハード ウェア的な方策により、同時に実現できる可能性がある。 ただし、直列型 FACTS 機器の動摇安定化能力は、その機 器が設置されている線路の潮流方向に依存するので、パラ レルフロー解消のための潮流制御動作が、その機器の動摇
抑制能力を劣化させる危険性がある。 そこで本論文では、TCSC か設置された電力ネットワー クにおいて、契約パスを伴った種々の電力取引を、TCSC の潮流制䘖と動摇安定化の観点からランク付けする手法を 提案する。提案手法では、各取引電力が契約パスの通りに 流れるように TCSC が潮流制御を行った場合、その潮流 制御の結果、TCSC の動摇安定化能力が向上するのか、あ るいは劣化するのかを、固有值感度などを利用して簡略な 評価を行う。そして、TCSC の安定化能力を向上させるま たは悪化させない電力取引に高いランクを付け、安定化能 力の劣化を招く取引に低いランクを与えて、そのランクを ベースに各電力取引の採択を決定する。本論文では、この ランク付け手法を電力取引経路フィルタ TPF(Transaction Path Filter)と呼んでいる(6)。

送電ネットワーク利用が開放された環境では、系統運用 組織にとって、種々の電力取引の物理的実現性と系統安定 度に及ほす影響を容易に評価でき、その採否を決定する方 法が望まれると考えられる。本論文で提案する TPF は、 TCSC の設置されたネットワークを前提とし、また TCSC のパラレルフロー解消制御能力と動摇安定化能力に基づい 
て電力取引のランク付けを行なうという限定された状況で の電力取引の採択決定手法であるが、その考え方は、ネッ トワーク利用の開放環境下における系統運用支援ツールの 基礎を与えるものと考えている。なお、本論文では、TPF の具体的手順を小規模なモテル系統を用いて説明している。

\section{2. 電力取引経路フィルタ TPF の考え方}

提案する TPF の基本的な考え方を図 1 と図 2 を用いて 説明する。まず、契約パスを伴った複数の電力取引が（図 1 には発電元 $\mathrm{G}$ と需要元 $\mathrm{L} の$ 間の取引のみを示している)、 系統運用組織に申し込まれたとしよう。このときTPFは、 各取引電力の全量がそれそれの契約パス上に物理的に流れ るようにするのに必要な TCSC の線路リアクタンス補償 量 $\mathrm{x}_{\mathrm{c}}$ を、各取引毎に算出する（図 2 の処理(1)）。次に、こ の TCSC の潮流制御か' TCSC の動摇安定化能力にどのよ うな影㸷を及ほすのかを、固有動摇モードの減衰特性から 各取引毎に別々に評価する（処理(2)。本論文では、この 評価を固有值実部の変化量 $\Delta \sigma$ を用いて行っている。

申し込まれたすべての取引に関して $\mathrm{x}_{\mathrm{r}}$ と $\Delta \sigma か ゙$ 得られ たならぱ、それらの値を用いて、各取引を以下の 4 つの ランクに分類する（処理(3))。まず、TCSC の制御限界範 囲内で取引電力の全量を契約パス上に流すことができ、す なわちパラレルフローを発生させず、かつその潮流制御の 結果が固有動摇モ一ドの隇衰特性を劣化させない取引を、 採択可能な取引として最も高いランク（図 2 中のランク A）に分類する。次に、TCSC の制御範囲内で取引電力の 全量を契約パス上に流すことができす、パラレルフローが 発生してしまうが、モードの減衰特性の劣化を招かない取 引を次のランク（ランク B）に分類する。同様に、パラレ ルフローを発生させないが、減衰特性を劣化させる取引を ランク C、パラレルフローを発生させ、かつ減衰特性も劣 化させる取引を最も低いランク D に分類する。

取引の採択は、ランク A、B、C に分類された取引に対 して行う（処理(4)）。採択の決定手順の詳細は、<3.2>節 で説明するが、その基本的な考え方は、固有モードの減衰 特性を劣化させないランク A、Bに分類された取引を優先 的に採択するようにする。たたし、複数の取引か同時に成 立するように TCSC を制御したときにその線路りアクタ ンス補償量から限界を超える場合には、減衰特性の劣化を

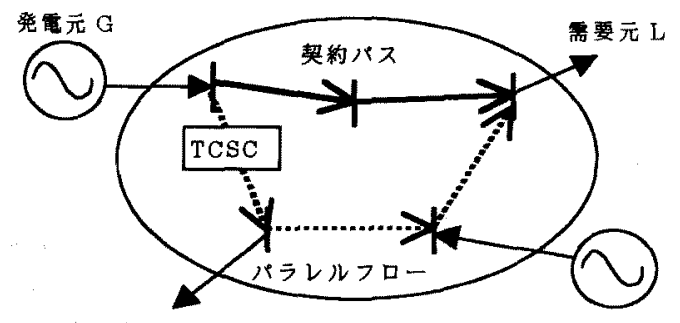

図 1 契約パスとバラレルフロー

Fig. 1 contract path and parallel flow
招くランク C の取引も含めて、TCSC の補償量が補償限 界内に入るように採択する最終的な取引を決定する。なお、 この段階で採択されなかった取引は、ランク D に分類さ れた取引と同様に扱われる。

ランク D に分類された取引は、TCSC が潮流制御を行 ってもパラレルフローを発生させてしまい、かつ固有動摇 モードの減衰特性を劣化させてしまうので、その取引経路 のままでは採択されない。そこで TPF では、減衰特性を 劣化させない新しい契約バスを各取引毎に算出し、その修 正した契約パスを取引の申し込み者に提示することになる (処理(5)）。この契約パスの修正法についてはく3.3>節で 詳述する。

\section{TPF の構成}

ここではTPFで行われる処理の詳細を説明する。

$<3.1>n^{\circ}$ ラルクロ一解消制御量と減衰特性变化量の新価

この節の内容は図 2 の処理(1)、(2)、(3)に対応している。 まず、図 1に示したように発電元 G と需要元 L の間で、 図中の太線の契約パスを伴った電力取引が行われると仮定 しよう。このとき、TCSC の潮流制御により取引電力の全 量が契約パスにながれたとしたときのネットワークの潮流 分布を $\mathbf{f} T$ とし、TCSCによる潮流制御を行わずに

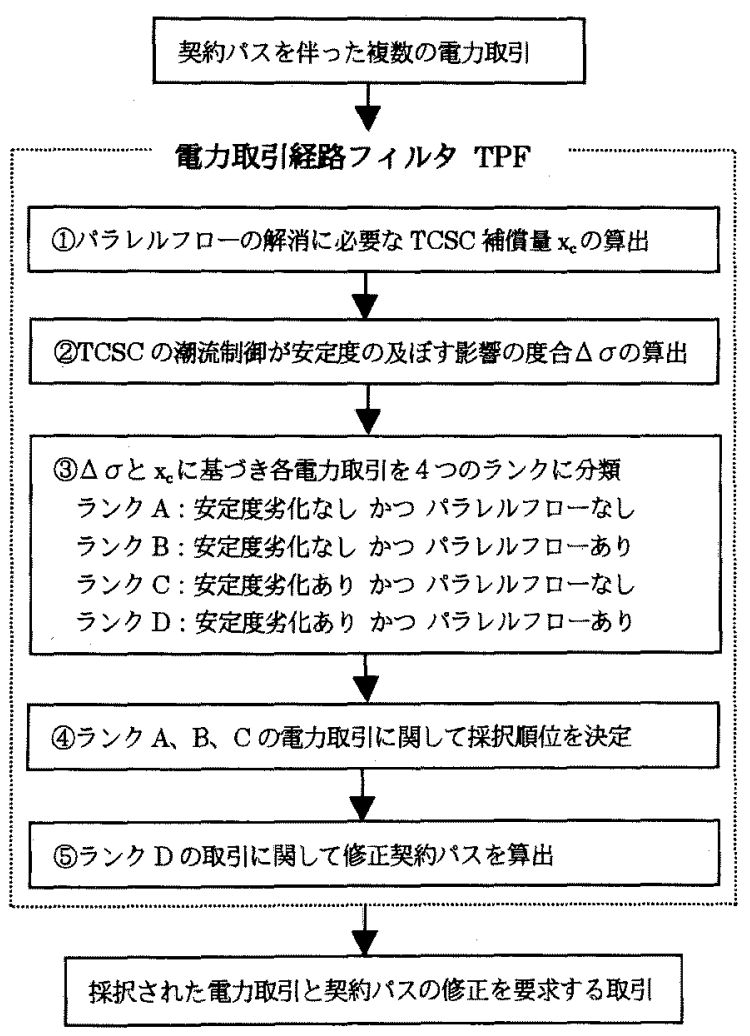

図 2 電力流通経路フィル夕

Fig.2 Concept of Transaction Path Filter 
GーL間の取引が行われたときの潮流分布を $\mathbf{f}_{N C}$ とすれば、 発生するパラレルフローf $P$ は、次式から求められる。 $\mathbf{f}_{P}=\mathbf{f}_{T}-\mathbf{f}_{N C}$

ここで、f $\mathbf{f} 、 \mathbf{f}_{N C} 、 \mathbf{f}_{P}$ はそれそれ線路の総数 $\mathrm{m}$ の次元を 持つベクトルである。

TCSC の潮流制御の目的は、このパラレルフローを 0 にすることであるので、それを達成するのに必要な TCSC の補償量 $\mathbf{c}$ は次式の最小化問題の解として得られる。

$$
\min _{\mathbf{x} c}\left[\mathbf{f} P-\mathbf{H} \mathbf{x}_{c}\right]^{T}\left[\mathbf{f} P-\mathbf{H} \mathbf{x}_{c}\right]
$$

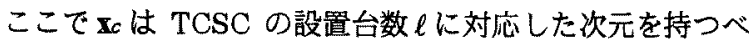
クトルであり、その各要素は TCSC の線路リアクタンス 補償量である。なお、本論文では、TCSC を付録 1 に示 す簡単なモテルで表現している。行列 $\mathrm{H}$ は、G-L 間の 取引電力がネットワークに注入された状態で得られる TCSCのリアクタンス $\mathbf{x}$ に対する潮流分布の感度を表し、 $\mathrm{m} \times \ell$ の行列である。なお、行列 $\mathrm{H}$ の算出方法を付録 2 に示している。

一般に TCSC の設置台数 $\ell$ は線路の総数 $\mathrm{m}$ より少ない と考えられるのて、（2)式の解は行列 $\mathrm{H}$ の左擬似逆行列を 用いて次のように求められる。

$$
\mathbf{x}_{c}^{*}=\left(\mathbf{H}^{T} \mathbf{H}\right)^{-1} \mathbf{H}^{T} \mathbf{f}_{P}
$$

TPF の処理(1)では(3)式を用いている。

上記のバラレルフロー解消制御が TCSC の動摇抑制能 力に与える影䉪は、次式を用いて評価することができる。

$$
\Delta \sigma=\mathbf{S} \mathbf{x}_{c} *
$$

ここで、 $\Delta \sigma$ は着目している固有動摇モードに対応する固 有値の実部の変化分を表すべクトルで、その次元は着目モ 一ドの個数に対応している。また、 $\mathbf{S}$ は、TCSC 設置線路 のリアクタンス変化に対する着目モードの固有值実部の感 度を表す行列である。固有值の実部が負であれば、対応す る動摇モードは時間と共に減衰するので、 $\Delta \sigma \leq 0$ とする 取引経路は固有動摇モードの減哀特性を劣化させないこと になる。逆に $\Delta \sigma>0$ とする取引経路は TCSC の動摇抑制 能力を低下させることになる。なお、本論文では、TCSC による動摇安定化制御を付録 3 に示すフロック図でモテ ル化している。また、固有值感度行列 $\mathrm{S}$ を付録 4 のシス テム行列に関して求めている。

TPF の処理(3)では、 $\mathbf{x}^{*}$ と $\Delta \sigma$ を用いて各取引を以下 の 4 つのランクに分類する。

ランク A : $\Delta \sigma \leq 0$ かつすべての TCSCの補償量に関し て $\left|x_{c i} *\right| \leq x_{c \max i}(\mathrm{i}=1,2, \ldots, \ell)$ が成立する。

ランク B : $\Delta \sigma \leq 0$ かつ少なくとも1台の TCSCの補償 量に関して $\left|x_{c i}{ }^{*}\right|>x_{c \max i}$ 占成立する。

ランク $\mathrm{C}: \Delta \sigma>0$ かつすべての TCSCの補償量に関して $\left|x_{c i}{ }^{*}\right| \leq x_{c \max } i(i=1,2, \ldots, \ell)$ が成立する。

ランク D : $\Delta \sigma>0$ かつ少なくとも 1 台の TCSC の補償 量に関して $\mid x_{c i}{ }^{*}>x_{c \max i}$ が成立する。

なお、TCSC の補償量がその限界 $\boldsymbol{x}_{c \text { max }}$ の箸囲内でパラレ
ルフローを解消できれば、(3)式から得られる $\mathbf{x}_{c} *$ のすべ ての要素の絶対值は $\mathbf{x}_{c} \max$ 以下であるので、ここでの分類 では、 $\mathbf{x} c^{*}$ の各要素が $\mathbf{x}_{c \max }$ を超えているか否かでパラレ ルフローの有無を判断している。

<3.2> 取引経路の探択手原この節では、TPF の 処理(4におけるランク A、B、C に分類された取引の採択 手順について図 3 を用いて説明する。説明では、9 種類の 取引 $t_{1}, t_{2}, \ldots, t_{9}$ が図のように 4 つのランクに分類されて いるものとする。また、一つの固有動摇モードの減衰特性 に着目しているとする。

はじめにランク Aに分類された取引の採択を決定する。 ランク $\mathrm{A}$ では $\mathrm{t}_{1}$ が着目モードの隇衰特性を最も劣化させ ない（ $\Delta$ oが負の方向で最大）取引なので、最初に $\mathrm{t}_{1}$ に ついて、パラレルフローの解消に必要な TCSC の線路り アクタンス補償量 $\mathbf{x}_{c l} *$ が限界 $\mathbf{x}_{c \max }$ の範囲内にあるのか をチェックする。t1 はランク A に分類されているので、 $\mathbf{x} c 1 *$ のすべての要素の絶対值が $\mathbf{x}_{c \text { max }}$ より小さいことは 明らかである。したがって、 $\mathrm{t}_{1}$ は採択されることになる。 次に、減衰特性の劣化度合が次に小さい取引 $\mathrm{t} 2$ について、 $\mathrm{t}_{1}$ と同様のチェックを行うか、今度は $\mathrm{t}_{1}$ と $\mathrm{t}_{2}$ のそれそれ の潮流制御に必要な TCSC 補償量 $\mathbf{x} c 1 *$ と $\mathbf{x}_{c 2} *$ の和に関し て、補償限界内にあるのかを調べる。なぜなら、 $\mathrm{t}_{1}$ と $\mathrm{t}_{2}$ に関するパラレルフローを同時に解消するためには、 TCSC の補償量を $\mathbf{x}_{c 1} *+\mathbf{x}_{2} 2 *$ とすればよいからである。し たがって、それらの和が限界内にあれば、パラレルフロー を発生させることなく、両方の取引を同時に成立させるこ とができる。しかし、それらの和が補償量の限界 $\mathbf{x}_{c \max }$ を 超えるとパラレルフローを発生させずに両方の取引電力を ネットワーク上に流すことができないことになるので、そ の場合は $\mathrm{t}_{2}$ の採択の決定を一時保留し、次の取引 $\mathrm{t} 3 に つ$ いて同様のチェックを行う。ここで取引 t 2 の採択決定を 一時保留する理由は、他の取引、たとえば $\mathrm{t} 3$ の採択が決 定された後に、あらためて $\mathrm{t}_{2}$ のチェックを行えば、t2も 採択される可能性があるからである。もし、社に関する TCSC の制御動作が容量性補償であり、taに関する動作か 誘導性補償であったとすれば、 $\mathbf{x}_{c 1}$ *と $\mathbf{x}_{03}$ *の符号は逆に なっている。すなわち、パラレルフローが発生しないよう に $\mathrm{t}_{1}$ と $\mathrm{t}_{3}$ のそれそれの取引電力を同時に流すのに必要な $\mathrm{TCSC}$ の補償量 $\mathrm{x}_{c 1} *+\mathrm{x}_{c 3} *$ は、 $\mathrm{t}_{1}$ のときだけに必要な補侻 量 $\mathbf{x}_{\mathrm{c}}$ *よりも少なくなる可能性がある。したがって、t3 の採択が決定された後に t 2 について再度チェックをすれ ば、 3 つの取引 $\mathrm{t}_{1} 、 \mathrm{t}_{3} 、 \mathrm{t}_{2}$ に同時に必要となる補償量 $\mathbf{x}_{11} *+\mathbf{x}_{c 3}$ * $+\mathbf{x}_{c 2}$ * は、限界 $\mathbf{x}<\max$ の範囲に入る可能性があ る。なお、ここの例で、 $\mathrm{t}_{1}$ と $\mathrm{t}_{3}$ が採択され、 $\mathrm{t}_{2}$ が採択さ れなかったと仮定すれば、 $\mathrm{t} 2$ の採択はランク $\mathrm{B}$ での評価 で再度検討されることになる。

ランク B に分類された取引の採択決定手順は、ランク Aの取引に対する手順と同一である。なおこの段階で新た に取引 $t_{4}$ が採択され、取引 $\mathrm{t}_{2} 、 \mathrm{t}_{5}$ の決定が一時保留され 


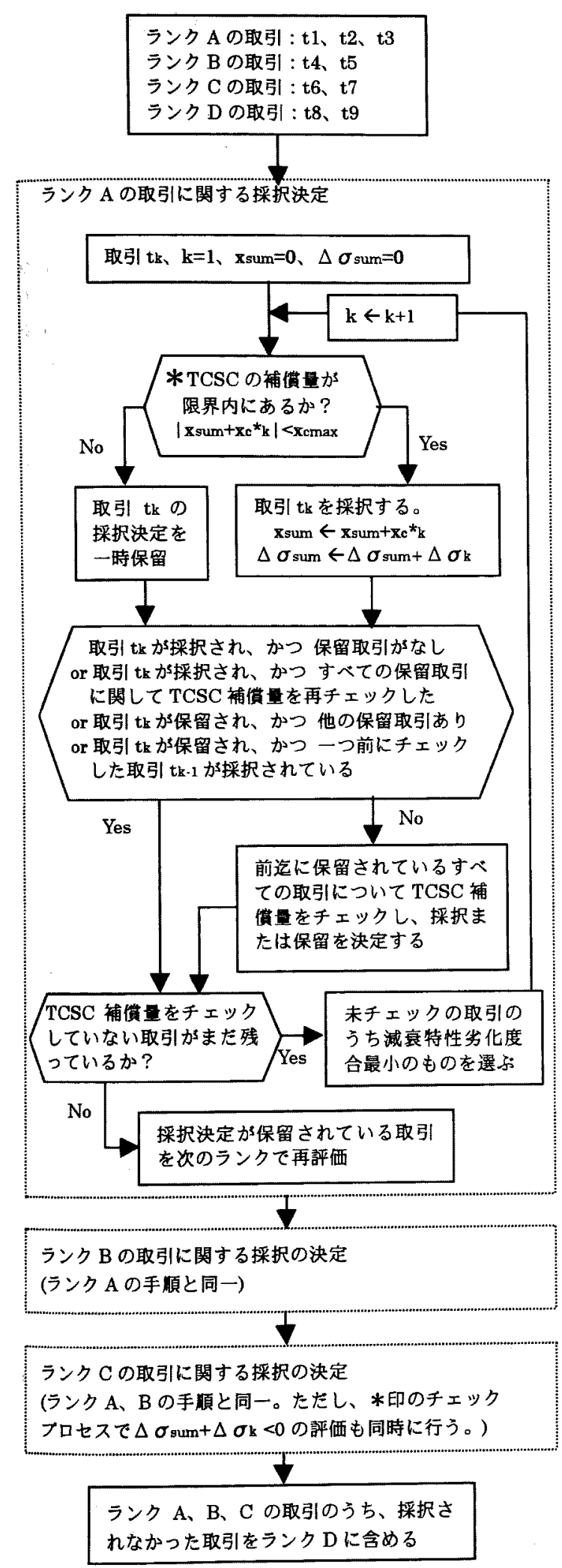

図 3 取引経路の採択アルゴリスム

Fig.3 discrimination algorithm for transaction paths
たとすれば、保留された取引の採択決定はランク C の決 定において再度検討される。

ランク $\mathrm{C}$ の取引に関する手順も、ランク A、B の手順 とほほ同じであるが、異なる点は隇衰特性の劣化度合いに 関するチェックを TCSC の補償量のチェックと合わせて 行う点である。ランク Cに分類された取引は着目モード の減衰特性を少化させる取引であるので、図示したように、 劣化度合の和 $\Delta \sigma$ sum が正にならないようにする必要があ る。

以上の手順の結果、取引 $t_{1} 、 t_{3} 、 t_{4} 、 t_{6} 、 t_{7}$ が採択され、 取引 $\mathrm{t}_{2} 、 \mathrm{t}_{5}$ が採択されなかったとすれば、 $\mathrm{t}_{2}$ と $\mathrm{t}_{5}$ はラン ク Dに分類された取引 t 8 、 t 9 と同様に TPF の処理(5)にお いて、取引経路の修正計算がなされる。結局、採択された 取引の各電力の全量をそれそれの契約パス上に同時に流す のに必要な TCSC の補償量は、採択された各取引の $\mathbf{x}_{*}^{*}$ の総和となる。また、その時の着目モードの減衰特性は、 採択された取引の $\Delta \sigma$ の総和の分だけ向上する（総和が 0 ならば取引発生前の減衰特性と同じ)ことになる。

$<3.3>$ 修正取引経路の決定の仕方 TPF の処理(5) では、ランク Dに分類された取引と、ランク A、B、Cで 採択されなかった取引について、申し込まれてきた契約パ スを修正した採択可能な取引経路を算出する。修正された 取引経路は、各取引毎に以下の最小化問題を解くことによ り求める。なお、ランク A、B、C、D の順に、同一ラン ク内では着目モードの隇言特性劣化度合の小さい取引から 最小化問題を解く。たとえば図 3 に示した取引の場合、 採択されなかったランク $\mathrm{A}$ の取引 $\mathrm{t} 2$ に関して最初に修正 経路を求め、次にランク B の採択されなかった取引 $\mathrm{t} 5$ 、 つついてランク D の t8、t 9 の順に修正経路を算出する。

目的関数 : $\min _{\mathbf{r} r r}\left[\mathbf{f} \mathrm{Pr}_{\mathrm{r}}-\mathbf{H} \mathbf{x}_{c r}\right]^{T}\left[\mathbf{f} \mathrm{P}_{\mathrm{T}}-\mathbf{H} \mathbf{x}_{c r}\right]$

制䄪:

(a)需給平衡条件 : $\mathbf{0}=\mathbf{A H} \mathbf{x}_{c r}$

(b) TCSC の補償量限界 : $\left|\mathbf{x}_{\text {sum }}+\mathbf{x}_{c r}\right| \leq \mathbf{x}_{c \max } \cdots \cdots \cdots \cdots(7)$

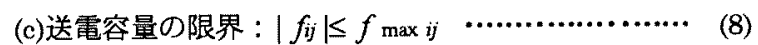

(d)着目モードの減衰特性劣化の回避 : $\Delta \sigma_{\mathrm{r}}=\mathbf{S} \mathbf{x}_{\mathrm{cr}} \leq \mathbf{0} \cdot(9)$

上記の备変数に付した添字 $\mathrm{r}$ は経路の修正を必要とする 取引の番号である。また、需給平衡条件を表す式は、TCSC が線路リアクタンス補償の動作をしても各母線への注入電 力は一定で、変化しないという仮定から導かれる。なお、 行列 A は接続行列である。TCSC の補償量限界を表す式 における $\mathbf{x}_{\text {sum }}$ は、TPF の処理(4)において採択されたラン ク A、B、C の取引に必要な TCSC の補償量と、取引 $\mathrm{tr}_{\mathrm{r}}$ の修正経路を求める前までに修正経路が決定された取引に 必要とした補償量の総和である。したがって、上述した順 番で修正経路が決定される毎に、Isum、すなわち、この 制的の範囲は変更されることになる。

取引 tr の修正経路は、その取引電力をネットワークに 
注入した状䭃で、上記の最小化問題の解 $\mathbf{x}_{r r}$ *の分だけ TCSC が線路補償を行なったときの潮流分布と、その取引 を行なう前の潮流分布との差として求められる。

\section{4. 小規模モテルによる検討例}

提案するTPF の妥当性を図 4 の線路抵抗を無視した小 規模モデル系統を用いて検討した。図中には取引発生前の 発電機出力、負荷、有効電力潮流を示している。この系統 には、 $0.71 \mathrm{~Hz}$ と $1.20 \mathrm{~Hz}$ の固有動摇モードが存在するが、 ここでの検討では $0.71 \mathrm{~Hz}$ のスローなモードに関する減衰 特性の劣化度合 $\Delta \sigma$ を TPF の評洒に用いている。また、 TCSC の動摇安定化制御には発電拣 1 の回転速度変化を 入力信号として用い、 $0.71 \mathrm{~Hz}$ モ一ドの動摇安定化に最も 効果のある線路にTCSCを設置した。取引発生前の $0.71 \mathrm{~Hz}$ モードに対応する固有值の夷部は、 -0.40 (減衰時定数 2.5 秒)であり、安定である。なお、最大補償時の TCSC の リアクタンス $\mathrm{x}$ を $25.6 \Omega$ としている。

表 1 は 3 種類の取引 $\mathrm{t}_{1} 、 \mathrm{t}_{2} 、 \mathrm{t} 3$ が申し込まれてきたとき の、各取引に対するランク付けと採択結果を示している。

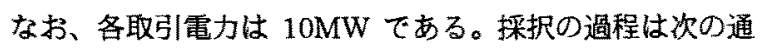
りである。まずランク A の取引のうち隇衰特性少化度合 の最も小さい取引 $\mathrm{t}$ が採択される。次にランク A の取引 t2 について TCSC の補償量 $\mathrm{x}$ の制限をチェックすると、

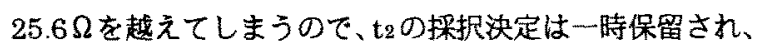
次のランク C の取引 $\mathrm{t}_{3}$ 以つて減衰特性の劣化度合と TCSC 補償量の制限を調へる。その結果、ぞちらも制限内 に入るので $\mathrm{t}$ は は採択されることになる。ここで保留され ていた $\mathrm{t} 2$ について改めて補償量のチェックをすると、 $\mathrm{t} 3$ が採択された結果、TCSC 補償量に余裕が出たため、t 2 も 採択されることになる。結局、パラレルフローを発生させ ず、かつ $0.71 \mathrm{~Hz}$ モードの減衰特性を劣化させないで（0.088 たけ固有值実部を負の方向人増加させている）、こ れら 3 つの取引電力を同時に各契約パス上に流せること

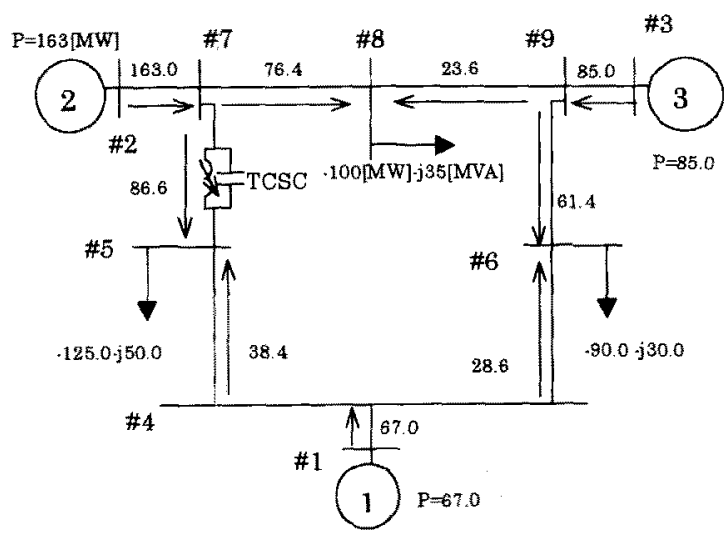

困4.小規模モデルと取引前の潮流分布

Fig.4 studied power system and power flows before occurring transactions
になる。

表 2 は、取引 th、t、、t6が申し込まれてきたときのラン ク付けと採択結果である。この場合も、ランク Aの取引 は採択される。しかし、ランク Cの取引ts または t6のい ずれを $\mathrm{t}_{4}$ と組み合わせても、 $0.71 \mathrm{~Hz}$ モードの固有值の赛 部が取引発生前のー0.40よりも悪化してしまうのて、t紋 t6 は採択されないことになる。

図 5は、t5、t 6 に関してTPF の処理(5)で求めた修正取 引経路である。これらの 2 つの取引が、修正経路のよう な契約バスで申し込みをすれば、TCSCの補償量の限界内 でバラレルフローは発生せず、かつ $0.71 \mathrm{~Hz}$ モードの減衰 特性を劣化させることはない。なお、図 5 に示した修正 経路は $\Delta \sigma=0$ とする結果になっている。

表 3 はランク A、B、Cの取引がそれぞんつずつある 場合の結果である。この場合、ランク B の取引 ts の採択 決定が一時保留された後、ランク C の取引toが採択され る。しかし、tsについて再度、採択決定の評価を行なって みると TCSC の補償量が制限を越えてしまい、 $\mathrm{t}_{8}$ は採択

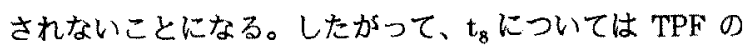
処理(5において修正取引経路の算出が行われることになる。

表 12 2つランク A 取引と 1 つのランク C 取引の採択結果 Table 1 a discrimination result for two Rank A-transactions and single Rank C-transaction

\begin{tabular}{|c|c|c|}
\hline 取引释路（马y顼） & $\Delta \sigma[1 / \mathrm{sec}]$ & $X \mathrm{c}[\Omega]$ \\
\hline t 1 (j/s $A)$ & -0.083 & -19.6 \\
\hline t2 (5y & -0.025 & -6.4 \\
\hline t 3 (方多C) & 0.020 & 4.8 \\
\hline \multicolumn{3}{|c|}{ 採択過程 $\downarrow$} \\
\hline $\begin{array}{l}\text { 取引経路 } \\
\text { (採択順) }\end{array}$ & $\begin{array}{c}\Delta \sigma \text { 積算值 } \\
\Sigma \Delta \sigma \leqq\end{array}$ & $\begin{array}{c}\mathrm{X}_{\mathrm{c}} \text { の積睯值 } \\
\left|\Sigma \mathrm{X}_{\mathrm{c}}\right| \leqq\end{array}$ \\
\hline$t 1$ & -0.083 & -19.6 \\
\hline $\mathrm{t3}$ & -0.063 & -14.8 \\
\hline $\mathrm{t2}$ & -0.088 & -21.2 \\
\hline
\end{tabular}

取引経路 t $1: \# 2 \rightarrow \# 7 \rightarrow \# 5 \rightarrow \# 4 \rightarrow \# 6$

取引经路 t $2: \# 3 \rightarrow \# 9 \rightarrow \# 8$

取引経路 t $3: \# 1 \rightarrow \# 4 \rightarrow \# 5$

表 21 つのランク A 取引と 2 つのランク c 取引の採択結果 Table 2 a discrimination result for single Rank A-transaction and two Rank C-transactions

\begin{tabular}{|c|c|c|}
\hline 取引释路（ラy順） & $\Delta \sigma[1 / \mathrm{sec}]$ & $\mathrm{Xc}[0]$ \\
\hline t $4(5 / 9)$ & -0.040 & -9.0 \\
\hline t5 $(3 \times h \mathrm{C})$ & 0.041 & 10.1 \\
\hline t $6(5) \mathrm{C})$ & 0.078 & 20.7 \\
\hline \multicolumn{3}{|c|}{ 採択過程 $\downarrow$} \\
\hline $\begin{array}{l}\text { 取引経路 } \\
\text { (採択順) }\end{array}$ & $\begin{array}{c}\Delta \sigma \sigma \text { 積算值 } \\
\Sigma \Delta \sigma \leqq 0\end{array}$ & $\begin{array}{c}\text { Xc の積算值 } \\
|\Sigma \mathrm{Xc}| \leqq 25.6\end{array}$ \\
\hline$t 4$ & -0.040 & -9.0 \\
\hline t 5 (不採択) & 0.001 & 1.1 \\
\hline t6 (不採抧) & 0.038 & 11.7 \\
\hline \multicolumn{3}{|c|}{ 取引経路 t $4: \# 2 \rightarrow H 7 \rightarrow \# 5$} \\
\hline \multicolumn{3}{|c|}{ 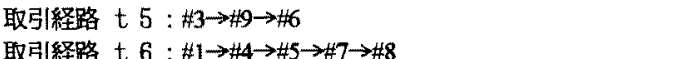 } \\
\hline 取引経路 t 6 : & & \\
\hline
\end{tabular}




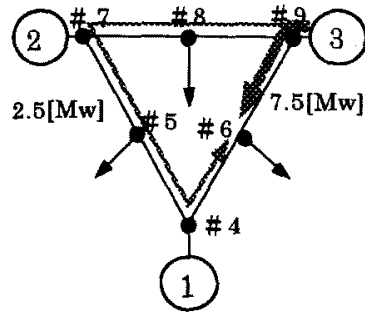

(a)取引 t5 の修正案

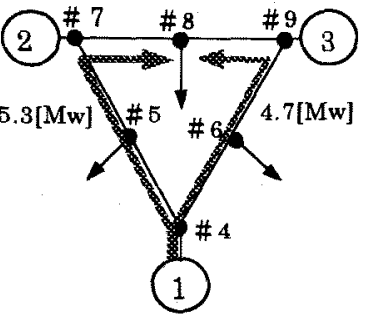

(b)取引 t6 の彩正案
図 5 修正された取引経路

Fig.5 modified transaction paths

表3 ランク A、B、Cの取引が一つつの場合の採択結果

Table 3 a discrimination result for a Rank A-transaction, a Rank Btransaction and a Rank $\mathrm{C}$-transaction

\begin{tabular}{|c|c|c|}
\hline 取引経路（うクク順） & $\Delta \sigma[1 / \mathrm{sec}]$ & $X \mathbf{c}[\Omega]$ \\
\hline t7 (ラソクA) & -0.083 & $-19 \cdot 6$ \\
\hline $\mathrm{t} 8(\bar{y} / \mathrm{B})$ & -0.124 & -30.2 \\
\hline t9(ラ⿰丿) & 0.078 & 20.7 \\
\hline \multicolumn{3}{|c|}{ 採択通程 $\downarrow$} \\
\hline $\begin{array}{l}\text { 取引経路 } \\
\text { (採把順) }\end{array}$ & $\begin{array}{c}\Delta \sigma \text { 皘算值 } \\
\Sigma \Delta \sigma \leqq 0\end{array}$ & $\begin{array}{c}\mathrm{Xc}_{\mathrm{c}} \text { の積算值 } \\
\left|\Sigma X_{c}\right| \leqq 25.6\end{array}$ \\
\hline$t 7$ & -0.083 & -19.6 \\
\hline t 9 & -0.005 & 1. 1 \\
\hline t 8 (不採択) & -0.129 & $-29 \cdot 1$ \\
\hline \multicolumn{3}{|c|}{ 取引経路 t $7: \# 2 \rightarrow \# 7 \rightarrow \# 5 \rightarrow \# 4 \rightarrow \# 6$} \\
\hline \multicolumn{3}{|c|}{ 取引経路 t $8: \# 3 \rightarrow \# 9 \rightarrow \# 8 \rightarrow \# 7 \rightarrow \# 5 \rightarrow \# 4 \rightarrow \# 6$} \\
\hline \multicolumn{3}{|c|}{ 取引释路 t $9: \# 1 \rightarrow \# 4 \rightarrow \# 5 \rightarrow \# 7 \rightarrow \# 8$} \\
\hline
\end{tabular}

以上の小規模モテルの検討結果から、電力取引経路の採 抧決定に関して次のような知見が得られた。

(1) 電力取引経路のランク付けは系統構成に依存する。 例えば図 4 のモテル系統の場合、TCSC に容量性の補償 動作をさせる反時計回りの取引経路が、固有モードの隇衰 特性を向上させる傾向にある。したがって、そのような取 引は高いランクに分類されることになる。

(2) ある取引経路の採否が、同時に発生した他の取引経 路に左右される可能性がある。例えば、表 2 のランクC の取引 $\mathrm{t}_{6}$ と表 3 のランク Cの取引 $\mathrm{t}_{9}$ は同一の取引経路で あるが、表 2 の場合は採択されず、表 3 の場合は採択さ れている。これは同時に発生したランクAの取引（表 2 の場合、 $\mathrm{t}_{4}$ 、表 3 の場合、 $\mathrm{t}_{7}$ ) がどの程度隇衰特性を向上 させるのかに依存している。

上記の 2 点は、送電ネットワーク利用の開放環境下に おける系統動特性情報の公開の重要性と難しさを示唆する ものと考えられる。すなわち、どのような流通経路が系統 の安定運用に好ましいのかという情報や、同時期の他の取 引経路に関する情報などか提示されないと、ネットワーク の利用者は申し込んだ取引経路がどのランクに分類される のかを事前に予測できないことになる。その結果、経済的 て、かつ経路の修正要求を受けないで阁むような取引経路 を、ネットワーク利用者側で事前に決定できない可能性が
ある。しかし、そのような情報が公開されることになれば、 一部の線路に取引経路の申請が集中するなどの系統運用を 困難にする危険性も出てくる。したがって、系統動特性情 報の公開の仕方は取引経路の申請手順と関連付けて十分に 吟味する必要があると言える。

\section{5. むすすひ}

本論文では、アメリカなどで問題になっている卸電力話 送取引に伴うパラレルフローと、その解消制御によって劣 化しうる FACTS 機器の動摇安定化能力に焦点を当て、系 統信頼度の維持の観点から各取引をランク付けし、その採 択を決定する新しい手法の電力取引経路フィル夕 TPF を 提案した。なお、提案手法を実用的な手法に近づけるため には、以下の項目についてさらに検討する必要がある。

（1）複数の TCSC が設置されている系統や着目する動摇 モードが複数の場合の TPF。

（2）申請されてきた各電力取引経路に関するバラレルフ ロ一解消制御量と減衰特性変化量をどの時点の系統状況 負荷状況において評価すへきか。また、その評価において 電力システムの非線形性をどのように考虑すべきか。

（3）TCSC の補償動作が短絡電流や電圧安定度に及ぼす 影響をどのようにTPFに組み込むか。

（4）想定事故、過渡安定度を考虑したTPF。

（5）TCSC 以外の FACTS 機器が設置されている場合や FACTS 機器の無い系統での TPF。

（6）米国で検傠されている取引電力量の削減方策と TPF の関連付け。

これらの課題が解决されれば、提案するTPF は、送電 ネットワーク利用が開放された環境において、有用な信頼 度評価ツールになり得ると考えられる。

なお、本研究の一部は共著者の皆藤が東北大学大学院に 在学中に行なったものである。

(平成 11 年 6 月 10 日受付、同 11 年 9 月 17 日再受付)

$$
\text { 文献 }
$$

(1) Current Operational Problems Working Group, "Operating Problems with Parallel Flow" , paper of IEEE /PES 1991 Winter Meeting ,91WM226-1PWR ,1 11,Feb.1991 (2)P. Johnson, "A Discussion Paper on Aligning Transmission Reservations and.Energy Schedules to Actual Flow". Attachment of NERC TRSSDWT Meeting Notes, Draft3-5-98 March, 1998 (http://www.nerc.com / filez /trssdwt.html) (3)岡本、横山、関根：「可変インビーダンス型電力系統の安定化制 御手法とその可変直列コンデンサ補偵系統への応用」電学論 B、 113 巻 3 号、203 208

(4) J. J. Pasrba, N. W. Miller, E. V. Larsen \& R. J. Piwko, "A Thyristor Controlled Series Compensation Model for Power System Stability Analysis" IEEE Transaction on Power Delivery Vol.10, No.3, July 1995

(5) 皆藤、斎藤 豊田：「セキュリティ維持のための予防的潮流制御に 関する基僣检討小平 10 年度電気関䋆学会東北支部連合大会、 2 A22

(6) Y. Kaito, H. Saitoh \& J. Toyoda : 「Stability Based Screening of Electricity Transaction Path」平 11 電気学会全大、No.1384 
付

\section{録}

\section{1. $\operatorname{TCSC}$ の簡略モテル}

TCSC を付図 1 のような可変リアクタンス $\mathrm{x}_{\mathrm{r}}$ として扱 い、 $\left|\mathrm{x}_{\mathrm{c}}\right| \leqq \mathrm{x}_{\mathrm{cmax}}$ の範囲で連続的に変更でるものとした。 また、計測時間やサイリスタスイッチの動作時間の遅れな どを無視している。

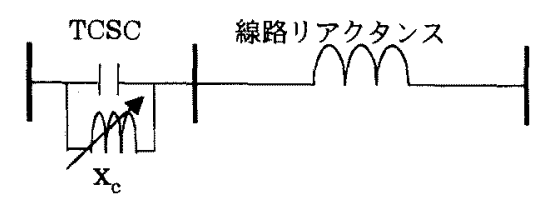

付図 1. TCSC のモデル

app. Fig. 1 a simplified model of TCSC

\section{2. $\operatorname{TCSC}$ の制御に対する湖流の感度}

$\mathrm{n}$ 母線 $\mathrm{m}$ 線路系統において、線路の抵抗を無視し、各 母線間の相差角が小さいと仮定すると、注入有效電力 $P$ $(\mathrm{n}-1$ 次元 $)$ と潮流分布 $\mathrm{f}(\mathrm{m}$ 次元 $)$ は、接続行列 $\mathrm{A}(\mathrm{n}-1 \times \mathrm{m}$ 次元)と母線位相角 $\delta(\mathrm{n}-1$ 次元)、TCSC を含めた線路リア クタンスからなる行列 $\mathrm{X}(\mathrm{m} \times \mathrm{m}$ 次元 $)$ を用いて次のように 表される。

$$
\begin{aligned}
& \mathbf{f}=\mathbf{X}^{-1} \mathbf{A}^{\mathrm{T}} \delta \\
& \mathbf{P}=\mathbf{A} \mathbf{X}^{-1} \mathbf{A}^{\mathrm{T}} \delta
\end{aligned}
$$

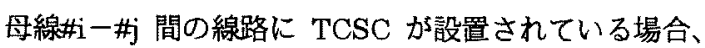
注入電力一定の条件下で、TCSC のリアクタンス $\mathrm{x}_{\mathrm{c}}$ に対 する潮流分布の変化分 $\Delta f$ は、次式で与えられる。

$$
\Delta \mathbf{f}=\left[\frac{\partial \mathbf{f}}{\partial x_{c}}\right] x_{c} \stackrel{\Delta}{=} \mathbf{H} x_{c}
$$

ここで、行列Hは、次式により与えられる。

$$
\mathbf{H}=\left\{\mathbf{X}^{-1} \mathbf{A}^{T}\left(\mathbf{A} \mathbf{X}^{-1} \mathbf{A}^{T}\right)^{-1} \mathbf{A}-\mathbf{I}\right\} \mathbf{X}^{-1} \frac{\partial \mathbf{X}}{\partial x_{c}} \mathbf{X}^{-1} \mathbf{A}^{T}\left(\mathbf{A} \mathbf{X}^{-1} \mathbf{A}^{T}\right)^{-1} \mathbf{P}
$$

\section{TCSCによる動播安定化制御}

付図 2 に示すように TCSC のリアクタンス $x_{c}$ を発電機 の回転速度変化に比例させて決定している。なお、入力信 号として利用する回転速度変化は、動摇㧕制の対鱼となる 固有動摇モードを多く含んだ発電機加ら計測するものとし ている。また付図 3 のように、慣性中心からの周波数偏 差の差が $0.1[\mathrm{~Hz}]$ とき、線路りアクタンスの $30 \%$ 0 補償が行われるように制御ゲインを設定している。ここで、 $+30 \%$ 補償は C 性補償であり、-30\%補償は L 性補償であ る。なお、対象モードに正の制動をかけるようにするため、
TCSC 設置線路の潮流方向に合わせて制御ゲインの符号を 決定している。

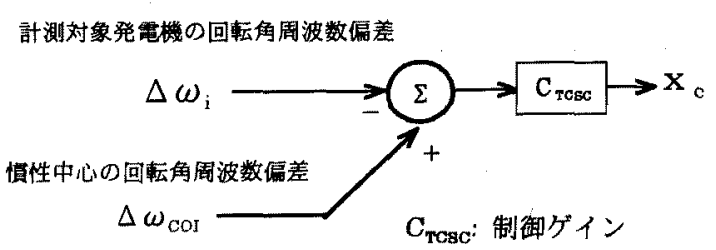

付図 2.TCSCの制御ブロック図

app. Fig. 2 block diagram of control system for TCSC

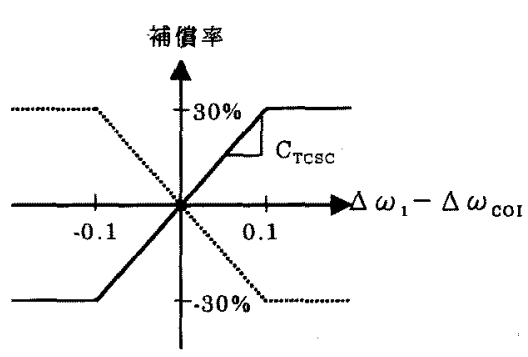

付図 3. 制御ゲインの特性

app. Fig. 3 characteristics of control gain

\section{4. 固有值感度行列 $S$ の算出}

発電機を過渡リアクタンス背後電圧一定モテルで表現し、 負荷を等価アドミタンスとして表して負荷ノードを縮約し たノードアドミタンス行列を用いたとき、TCSC の制御効 果を考虑した動摇方程式は次式のように表わされる。

$$
\mathbf{M} \frac{d^{2} \delta}{d t^{2}}=\mathbf{P}_{\mathbf{m}}-\mathbf{P}_{\mathrm{e} 0}-\left.\frac{\partial \mathbf{P}_{e}\left(x_{c}\right)}{\partial x_{c}}\right|_{\nu=v_{0}, \delta=\delta_{0}} x_{c}
$$

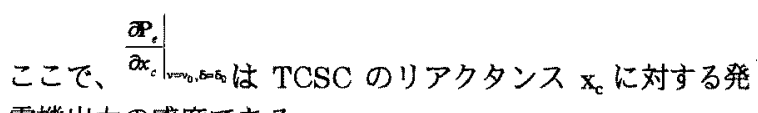
電機出力の感度である。

(付 5)式を、運転点周りで線形近似をし、一階の微分項 で整理すると次式が得られる。

$$
\left[\begin{array}{c}
\Delta \dot{\delta} \\
\Delta \dot{\omega}
\end{array}\right]=\left[\begin{array}{ccc}
0 & 1 & \\
-M^{-1} \mathbf{K}\left(x_{c}\right) & -\mathbf{M}^{-1}\left(\left.\frac{\partial P_{e}\left(x_{c}\right)}{\partial x_{c}}\right|_{v=v_{0}, \delta=\delta_{0}}\right.
\end{array}\right]\left[\begin{array}{l}
\Delta \delta \\
\Delta \omega
\end{array}\right]
$$

ここで、K は同期化力係数行列、 $\mathrm{G}$ は付図 2 のプロック 図から定まる行列である。

固有值感度行列 $\mathrm{S}$ は(付 6 )式のシステム行列から求めて いる。 


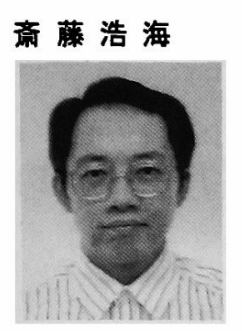

（正員）1960年 7 月 19 日生。1989年 3 月 東北大学大学院工学研究科博士課程修了。 同年 4 月同大学工学部助手、1992 年 4 月 同助教授、現在に至る。工学博士。IEEE 会貝。

皆藤佳孝

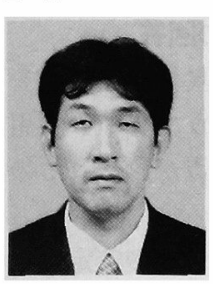

豊田淳一

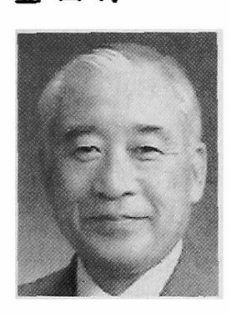

（正員） 1972 年 7 月 6 日生。 1997 年 3 月 東北大学工学部電気工学科卒業。1999 年 3 月同大学大学院工学研究科博士前期 2 年 の課程修了。同年 4 月東京電力(株)入社、 現在に至る。
（正貝）1934年 7 月 9 日生。1963年 3 月 東京大学大学院博士課程修了。同年 4 月 成蹊大学工学部電気工学科助教授、1972 年 4 月同教授。1983 年 4 月東北大学工学 部電気工学科教授、1998 年 3 月同停年退 官。同年 4 月八戸工業大学工学部電気工学 科教授、現在に至る。工学博士。東北大学 名誉教授。IEEE,CIGRE 会貝。 
電力・エネルギー部門大会座長のコメントと回答

- A 03 規制緩和 (1) -

\section{質 疑}

座長 田辺㦀也

\section{1. 同セッションでの対象論文への質疑応答}

(1)

$\mathrm{Q}$ ：潮流状態により大きく取引経路の優先順位が変動する と考えられるが，多断面の評価をこの手法を用いてど のよう行うのか？

A：どの時点の潮流状態を用いて評価すべきか。また，そ の評価においてシステムの非線形性をどう扱うかは重 要な課題であり, 今後檢討を進めたいと考えている。

(2)

$\mathrm{Q} ： \operatorname{TCSC}$ を論文のように導入していくと，安定度が琶 化してしまうのではないか？

A：提案手法は系統信頼度維持の観点からのランク付けで あり，パラレルフロー問題の解决と系統安定度の維持 とを両立できる可能性があると考えている。

(3)

$\mathrm{Q}$ ：現実問題としてTCSC が導入されていくのか？

$\mathrm{A}$ : TCSC 等の FACTS 機器は高速な潮流制御, 電力動 摇抑制などに有効であるので，今後導入が検討されて いくと考えている。

2. 著者に照会したい座長コメント

論文の中で「系統動特性情報の公開の仕方は取引経路の 申請手順と関連づけて十分に吟味する必要があると言え る」と述べている。つまり，系統動特性情報の公開に対す る何らかの具体的方策・考方方が示されてこそ，この論文 の有用性が発揮されるのではないかと考えます。そこで， 系統動特性情竍の公開方法についての具体的なお考之があ りましたら教えて下さい。
応答

$\begin{array}{ll}\text { 斎藤 } & \text { 浩海 (東 北大) } \\ \text { 皆藤 } & \text { 佳孝 (東京電力) } \\ \text { 豊田 } & \text { 澺一 (八戸工大) }\end{array}$

「著者に照会したい座長コメント」への回答

系統動特性情報の公開方法については具体的な検討をし ておりませんが，系統運用組織が送電ネットワーク利用者 に提示する必要のある情報には，次の 2 点が含まれるのて はないかと考えて扔ります。

（1）ネットワーク利用者が電力システムの安定度を考 慮して電力取引経路を選定するための情報

（2）系統運用組織がネットワーク利用者に取引経路の 修正を要請する場合の情報

（1）に関する情報として，電力取引に使用可能な各線路 の送電容量が必要になると考光られます。なお，この送電 容量法引電力の注入点と引出点の組み合わせごとに算定 され，その算定において系統の安定度や各種電力没㣁・制 御譏器の限界などが考慮されることになると思います。ま た，この送電容量は系統状況に依存しますので, 発電機出 力分布, 負荷分布, 系統構成などの変化に合わせて随時更 新するか，あるいは，ある将来時点までの一定期間にわた って予测した送電容量を提示する必要があると考えられま す。

このような送電容量に関する情報が提示されれば，ネッ トワーク利用者は, 系統の安定連用に好ましい取引経路, すなわち本論文で言うランク A に相当する経路を申請し てくるものと予想されます。ただし，本論文で述べました ように，単独では採択され得る取引経路でも，同時に複数 の取引が生じると TCSCの制御限界の制約などから，必 ずしもすべての取引が採択されるとは限らない状況が発生 します。したがって，提案する電力取引経路フィル夕 TPF のようなある明確な規準に基づいて各取引に採択順 位をつける手法が，ネットワーク利用の開放環境下におい て重要になると考えております。

（2）に閔する情報は，取引経路の修正が必要になる理由 を亦ットワーク利用者に明示するために必要であり，その 内容としては，申請した取引経路が系統の安定度劣化やパ ラレルフローの発生にどのような影響を与えるのかを明確 にできるものでなければならないと考えられます。

な执，ネットワーク利用者に提示すべき具体的情報とそ の提示の仕方を考えるうえで，アメリカのNERCで検討 されているATC (Available Transmission Capability) の定義・算定方法などが参考になるものと考えています。 